\title{
TEMA E VARIANTES DO MITO: SOBRE A MORTE E A RESSURREIÇÃO DO BOI
}

\author{
Maria Laura Viveiros de Castro Cavalcanti
}

\begin{abstract}
We are instruments of our instruments. And we are necessarily susceptible to the particular ills that result from our prowess in the ways of symbolicity. Yet, too, we are equiped in principle to join in the enjoying of all such quandaries, until the last time.

Kenneth Burke (1984 [1966]:viii)

"Este boi bonito não deve morrer, porque só nasceu para conviver". Cantiga do Reisado do bumba-meu-boi.

Sílvio Romero (1954:350)
\end{abstract}

Um boi-artefato, que baila, morre e ressuscita, é foco de brincadeiras pelo país afora: 'Boi-Bumbá', no Amazonas e no Pará; 'Bumba-meu-boi', no Maranhão; 'Boi-calemba', no Rio Grande do Norte; 'Bumba-de-reis' ou 'Reis-de-boi', no Espírito Santo; 'Boi-pintadinho', no Rio de Janeiro; 'Boi-de-mamão', em Santa Catarina, entre outros. Para além da diversidade regional expressa nessas denominações, o conjunto de variantes da "brincadeira do boi" é heterogêneo e vital ${ }^{1}$.

Este texto indaga sobre a presença e o sentido de processos míticos na brincadeira, em uma abordagem de inspiração estruturalista (Lévi-Strauss 1967, 1971, 1976, 1993; Leach 1969; DaMatta 1973, 1979). Tarefa intrincada, pois é preciso inicialmente relativizar a renitente idéia, proposta pela bibliografia, de que o folguedo do boi corresponderia, ou teria correspondido em suas supostas origens, à encenação de um auto. Como argumento, o "auto" é sobretudo a crença dos pesquisadores no auto, em uma notável cristalização do efeito de ilusão do arcaísmo, característico dos estudos folclóricos e também antropológicos da cultura popular, tão bem examinado por Belmont (1986). A primeira parte deste texto busca, assim, situar em novos termos o 
"problema do auto" entendendo-o como um conjunto de narrativas de origem que emerge nesse campo de estudos na esteira da atuação do movimento folclórico (Vilhena 1997a). Assim delimitado um conjunto narrativo, elegi nove entre tantas variantes, e sua análise embasa a demonstração da natureza mítica do processo simbólico em curso. Nas conclusões, busco repensar as relações entre mito e rito nos folguedos do boi.

A natureza das questões propostas requer assim um plano próprio de abstração e generalização para o seu exame que, vale assinalar, trabalha com base em pesquisas etnográficas de duas modalidades da brincadeira. São elas o festival dos Bois Bumbás de Parintins /Amazonas (Cavalcanti 2000, 2002a, 2002b, 2004) e o universo cheio de matizes do Bumba-meuboi maranhense (CNFCP 2003b; Carvalho 2005; Carvalho 1995; Albernaz 2004) $)^{2}$. À luz da experiência dessas pesquisas, teço um comentário inicial sobre a literatura percorrida ao longo do qual delineia-se o plano analítico em que as indagações sobre um "mito" do boi situam-se. ${ }^{3}$

\section{O mito (na acepção evolucionista) e o "auto"}

A amplitude temporal dos estudos sobre a brincadeira, que conformam a maneira pela qual o passado do folguedo chega intelectualmente a nós, configura um heteróclito conjunto. São registros e pesquisas feitos por cronistas, viajantes, estudiosos de diferentes matizes e formação que podem ser reunidos em dois grupos temporais: os do século XIX e os do século XX. Os registros do primeiro grupo datam dos primórdios do século XIX e indicam o Norte e o Nordeste como as regiões de formação bem como a localização via de regra urbana do folguedo ${ }^{4}$. Neles, variam a inserção do brinquedo no calendário festivo-natalino no Nordeste e junino no Norte, e também os personagens que brincam em torno do boi (Cascudo 1952:448461; Salles 1970). De simples notas a descrições mais elaboradas, esses registros expressam, sobretudo, o interesse dos cronistas em criticar, relatar ou louvar um peculiar costume popular (Avé-Lallemant 1961; Lopes Gama 1996; Sacramento 1979; Sanches Frias 1883).

Interessam-nos aqui especialmente os registros realizados no século XX, quando o interesse pelo folguedo muda nitidamente de caráter, passando a alimentar de modo marcante a busca de "brasilidade" por parte da intelectualidade. Nesse novo momento, registros e interpretações imbricaram-se de modo inextrincável. Sobretudo entre as décadas 1940-60, a aspiração nacionalista dos estudos de folclore buscou na cultura popular um modelo de autenticidade orientado por uma visão romântica e harmônica da vida social (Cavalcanti et 
alii 1992; Vilhena 1997a; Cavalcanti 2004; Stocking Jr. 1989; Zengotita 1989; Duarte 2004). Visões racialistas da cultura, celebrando os ideais de mestiçagem, freqüentemente também se fizeram presentes (Andrade 1982; Cascudo 1984). Essa bibliografia construiu para o folguedo do boi um lugar ideológico singular que sobredetermina a maneira pela qual hoje o conhecemos.

Em especial, Mário de Andrade expressou clara predileção pelo Bumba. Na complexa arquitetura de sua obra, o Bumba-meu-boi ergueu-se como modelo estético e símbolo paradoxal de uma possível unidade cultural nacional (Moraes 1978, 1983, 1992; Lopez 1972; Mello e Souza 1979). A imensa influência do autor sobre gerações subseqüentes de estudiosos da cultura popular pode ser percebida na afirmação recorrente desse leit-motiv: o folguedo do boi seria o mais exemplarmente "brasileiro"5.

Nas formulações sobre as danças dramáticas, Mário de Andrade (1982) alimentou também a reflexão sobre o bumba-meu-boi de uma dimensão conceitual mais profunda (Cavalcanti 2004), ao encontrar o princípio de sua unidade no tema "mítico" da morte e da ressurreição do boi. "Mito" era noção entendida na acepção evolucionista ${ }^{6}$. O Boi "animal totêmico", elemento isolado de contextos narrativos ou etnográficos, guiou a compreensão das origens e do nexo do folguedo. A noção de mito utilizada por Andrade tende, como assinalou Détienne (1992), a essa quase desrazão atribuída aos "primitivos" e ao "povo", a uma outra forma da razão humana, cuja obscuridade lógica e intensidade afetiva produzem a um só tempo fascínio e repulsa.

A noção evolucionista de mito ocupou, assim, lugar-chave no esquema conceitual dessa "dança dramática", permitindo atribuir ao "boi" que morre e ressuscita a significação de ícone e indício de uma camada primitiva da humanidade, ainda presente na mentalidade e nas práticas das camadas populares brasileiras. O "tema mítico" da morte e da ressurreição do boi propiciaria ao folguedo uma "estrutura central", um "núcleo fixo", um "eixo", enfim, pois seria dramatizado no "entrecho" central ao qual se acoplariam as múltiplas encenações da "rapdósia". Para Andrade, o "mito" seria, em suma, a chave da compreensão do folguedo ${ }^{7}$.

Nas visões subseqüentes, a idéia andradiana de que o núcleo de sentido situar-se-ia no "entrecho dramático" mítico amalgamou-se à idéia difusa de que o folguedo do boi corresponderia, em suas supostas origens, à encenação do enredo de um auto. Ascenso Ferreira (1944), colaborador de Mário de Andrade e autor de registro sobre o Boi de Afogados no Recife, cita expressamente um trecho das Danças Dramáticas para corroborar a impressão de ser o bumba-meu-boi "o mais nebuloso dos bailados populares do nordeste" pois, tendo sido outrora um auto, "do enredo desse auto é que se perdeu indiscutivelmente o 'roteiro'" (1944:52) . 
A partir da segunda metade do século XX, os estudos disponíveis cristalizaram em uma espécie de narrativa canônica - o enredo de um suposto auto-o papel de chave da inteligibilidade do folguedo (Queiroz 1967; Meyer 1991; Monteiro 1972; Ferreira 1944; Borba Filho 1966; Cascudo 1984; Salles 1970; Carvalho 1995; Lima 1982; Marques 1999; Azevedo Neto 1983). Convido à leitura de uma dessas narrativas, aquela que, por sinal, nos servirá de referência na análise.

\section{Versão 1. Relato de Bordallo da Silva (1981:51)}

O motivo principal do auto é a posse de um boi famoso, pelas suas qualidades e valentia, que o amo ou fazendeiro deu de presente à sua filha e confiou aos cuidados do vaqueiro. Mãe Catirina desejou comer aquele famoso boi, pois estava grávida e com entojos. Pai Francisco, seu marido, não teve dúvidas em tentar matá-lo para satisfação de sua mulher. Desaparecido o boi, o vaqueiro chefe é chamado para dar conta do que lhe fora confiado e este descobre que Pai Francisco havia atirado no boi. Pai Francisco resiste à prisão e os vaqueiros confessam sua fraqueza em trazê-lo preso. Assim, é chamado o tuxaua de uma tribo de índios. Pai Francisco é preso pelos silvícolas e somente será dispensado do castigo, que bem merece pelo seu crime, se ressuscitar o boi. Aterrado, ele chama o 'doto', e o 'padre' em pura perda, apesar dos esforços de ambos. É lembrado então o pajé da taba. Este, depois de muitos exorcismos, danças com maracá e baforadas de cigarro envolto em tauari [Curataria tavary] logra o milagre de fazer reviver o 'animal'. O acontecimento é festejado com extrema alegria, e o bando, sempre cantando, "dá a despedida".

O folguedo do boi consistiria, então, basicamente, na encenação do "auto" do boi, como se o "enredo" do "auto" fornecesse, ou tivesse outrora fornecido, seu roteiro fiel. Com esse entendimento, dois problemas nublam a compreensão antropológica da brincadeira. A idéia de um "enredo" é, por si só, enganosa. Como já alertaram Jakobson e Bogatyrev (1973), essa noção erudita, ao propor uma correspondência direta entre "texto" e "ação", turva a compreensão dos processos criativos populares ${ }^{9}$. Ao mesmo tempo, a suposição da existência de um auto originário parece ser produto de uma ilusão (Belmont 1986). Pois curiosamente, embora grande parte dos pesquisadores e brincantes pareçam crer no "auto", ele raramente ocorre nos circuitos propriamente populares da brincadeira, onde deparamo-nos sobretudo com a constante reiteração de sua falta. Apenas nos circuitos parafolclóricos podemos encontrá-lo com mais freqüência.

Carvalho (2005:28-92) relatou em detalhes sua sofrida busca de um "auto" no bumba-meu-boi maranhense. Auto que afinal inexistia, ao menos 
na forma normativa em que é geralmente concebido. Sua pesquisa permite situar o "auto" como apenas uma das diferentes possibilidades de narrativas e encenações cômicas potencialmente presentes em uma das variantes do bumba maranhense, "o sotaque de Zabumba", famoso justamente por aproximar-se da "tradição"10.

A explicação do folguedo pelo suposto "auto" é, no mínimo, uma redução pois, como experimentamos todos os que pesquisamos esse denso universo etnográfico, muitas coisas acontecem para além do "auto", ou mesmo na sua ausência. Mesmo quando existente, a relação entre os elementos do "auto" e a ação coletiva concertada está muito distante da correspondência mais direta que há nas formas dramáticas eruditas ${ }^{11}$.

No Bumbá de Parintins, a relação entre o suposto auto e as performances concretas tende à alusão. Quando comecei a pesquisar esse Bumbá em 1996, os personagens-chave do auto - Boi, Pai Francisco, Mãe Catirina, Amo do Boi, Sinhazinha da Fazenda, Pajé - faziam-se presentes em seqüências dramáticas fragmentárias às quais se sobrepunha, de modo marcante, um plano narrativo oriundo dos temas anuais relativos ao imaginário lendário amazônico. Não havia ênfase especial em uma seqüência dramática integral que apresentasse o auto. Essa história me foi narrada em contextos extrarituais por interlocutores premidos, de certo modo, pela necessidade de me explicarem de que o Bumbá afinal tratava (Versão 2).

Entretanto, o conjunto característico dos personagens "do auto" (acrescido de vários outros) figurava nas performances, lançando uma rede de sentido esgarçada sobre a multiplicidade de seqüências dramáticas fragmentárias. O próprio tema da morte e da ressurreição do boi deslocara-se para uma temática de cunho indianista, elaborada na seqüência final, denominada ritual e atuada pelo pajé. Em Parintins, eram populações indígenas amazônicas antigas que morriam no ritual e eram, de certo modo, ressuscitadas pela festa cabocla (Cavalcanti 2000, 2002b).

Suspeitemos, pois, do auto. A idéia de um enredo para o auto seria, então, simples racionalização nativa, ingenuamente incorporada como explicação pelos pesquisadores? O problema sugere análise mais detida e alguma reflexão sobre as relações entre mito e rito no contexto da brincadeira. Sob que formas concretas, afinal, a brincadeira do boi se nos apresenta?

\section{O tema do boi: do "auto" às narrativas de origem}

Em um pequeno artigo sobre as formas de crença e racionalidade na Grécia Antiga, Jean Pierre Vernant (2001) distingue três lugares nos quais pode- 
TEMA E VARIANTES DO MITO: SOBRE A MORTE E A RESSURREIÇÃO DO BOI

mos encontrar o que chamamos de "crer". Seriam eles: os ritos - a ação humana concertada e expressiva; as imagens, os ídolos e os artefatos - as formas de figuração; e os mitos - as narrativas orais desprovidas de dogmas ou teologia ${ }^{12}$

Louis Dumont (1987) busca também a compreensão integrada da Tarasque por meio da descrição etnográfica do rito, da iconografia e das lendas eruditas associadas a representações e a narrativas locais ${ }^{13}$.

O uso flexível e etnográfico dos conceitos de mito, rito e figuração em tais abordagens é sugestivo. Essas noções são eficazes porque permitem apreender níveis de realidade distintos no folguedo do boi. Ao mesmo tempo, vale não perder de vista as insistentes lições de Mauss (1978) a nos lembrarem a natureza integrada do homem e de suas produções. Nesses diferentes planos de existência dos fatos - narrativas, ações e figurações - como já sugeriu Lévi-Strauss (1967, 1993), articulam-se muitas vezes processos mentais de natureza assemelhada. Mas é preciso distinguir para analisar, comparar e finalmente integrar.

Antes de mais nada, o "boi" é um artefato que dança animado por pessoas que dentro dele se enfiam. Já nas descrições do século XIX, esse objeto bailante é o elemento físico recorrente em todas as modalidades do folguedo, em torno dele agrega-se um grupo de brincantes cuja designação é clara: um "bombá", bumbah, bumba-meu-boi. Palavras cuja sugestiva ambivalência etimológica vale assinalar: bumba ou bumbá = surrar, bater e dançar (Borba Filho 1966:10; Cascudo 1984:150).

Um grupo humano que brinca em torno de um boi-artefato realiza um comportamento simbólico por excelência. Esse primeiro grupo de registros evidencia assim a primazia da ação ritual festiva e lúdica na articulação dos processos de simbolização inerentes ao folguedo (Durkheim 1978; Valeri 1994).

Nas formas contemporâneas, o boi é também emblema dos grupos brincantes: Boi da Fé em Deus, Caprichoso, Garantido, Tira-teima, Corre campo. Uma forte afetividade permeia a vinculação do grupo ao "boi" (emblema e artefato) que brinca na rua, no terreiro, na praça ou na arena. Um "boi" pede a existência de outro e o universo do folguedo é também intensamente relacional, configurando um processo de vinculação em que a adesão a um grupo significa simultaneamente o estabelecimento de forte rivalidade com outros (Valentin 2005).

A brincadeira aciona diferentes linguagens expressivas: há música (conjunto de instrumentos, voz cantada e falada); há bailados (coreografias específicas para personagens e fases da brincadeira); há também drama (seqüências de ação nas quais interagem certos personagens da brincadeira). Contra esse pano de fundo etnográfico vale reformular o "problema do auto". 
Em diversas formas do folguedo há efetivamente a presença de um sistema de personagens e ações reunidos em torno do tema da morte e da ressurreição do boi. Essa presença manifesta-se de vários modos. O boi - emblema e artefato - é sempre figurado em objetos, desenhos, pinturas e bordados ${ }^{14}$. Nas performances, indumentárias variadas e características compõem os tipos cênicos ${ }^{15}$. Coreografias particulares acompanham essas figuras e, em alguns casos, também a participação do público. Alguns personagens realizam pequenas seqüências dramáticas, eventualmente cômicas (Cavalcanti 2000; Carvalho 2005). Além disso, diversas lendas e fabulações extrapolam o contexto ritual e se fazem presentes na poesia de toadas que circulam também em um dinâmico segmento do mercado fonográfico contemporâneo. Entre as muitas possibilidades poéticas, encontram-se temas propostos pelas narrativas do "auto" (Versão 3$)^{16}$.

Porém, vale insistir que um grupo de boi não necessariamente encena uma seqüência dramática que reúne ação cantada e dialogada por parte dos personagens característicos postos em relação pelo tema da morte e da ressurreição do boi. Pode não fazê-lo nunca, e as ações dramáticas do "auto" são evocadas por meio de frouxos mecanismos alusivos ${ }^{17}$. Pode fazêlo apenas em certo tipo de apresentação, ao longo de um amplo ciclo anual, pois o ritmo de vida desses grupos é regido pelo calendário festivo católico em suas versões populares e turísticas (Carvalho 1995). Quando o faz, essa encenação não é nem a única nem a mais importante do ponto de vista dos brincantes. Ultimamente, ela resulta sobretudo da forte pressão da idéia "oficial" de que é preciso manter viva a "verdadeira tradição".

À luz dessas observações, é hora de considerar a crença no auto como um fato social pleno (Durkheim 1978) e de indagar sobre a força ativa que essas narrativas exercem nas interpretações intelectuais e nos contextos etnográficos da brincadeira.

Ora, vale observar que essas narrativas do auto emergem apenas nos estudos realizados a partir de meados do século XX. Seus primeiros registros parecem ter sido suscitados no bojo do afã colecionista dos estudos de folclore (Vilhena 1997a). Diante desse fato, tudo indica serem as narrativas do auto, em si mesmas, o produto do interesse erudito pela cultura popular ${ }^{18}$. Elas acusam não o recolhimento neutro de uma autenticidade original e intocada, mas antes o ingresso de formas de cultura até então predominantemente orais no universo do registro da escrita (Vilhena 1997b; Goody 1977; Goody e Watt 1968; Barltett 1965). Os relatos que nos chegam através desses estudos, e através deles se mantêm vivos na tradição popular, acusam uma mudança profunda no sistema de registro e transmissão da brincadeira: a chegada da escrita, via interesse erudito, a tradições até então predominantemente orais ${ }^{19}$. 
É como se essa história de boi reproduzisse em nosso país as discussões da antropologia da religião em finais do século XIX, com o tema crucial do relacionamento entre mito e rito, da solidariedade entre palavras e gestos. Como elucida Détienne, em resenha desses debates evolucionistas (1987), o rito era então visto como o elemento mais primitivo: dança, gesto ativo, que precederia palavra e dela prescindiria. O rito seria assim não só primordial como "silencioso". A noção de "mito" como fabulação explicativa preencheria esse silêncio. Em especial, quando a tradição falta, nos indica o autor, comentando trabalhos que desenvolvem esse tipo de argumento, os guardiões fabulam (1987:59). Na segunda metade do século XX, os folcloristas e os pesquisadores brasileiros parecem então ter operado dentro de uma ótica evolucionista, funcionando como guardiões dessa tradição ritual já ausente ou claudicante ao registrarem as narrativas da "origem" 20 .

Ocorre porém que, ao registrarem relatos que aludiam a tempos antes míticos do que históricos, os pesquisadores viram-se vítimas da ilusão do arcaísmo, tomando por história real episódios de natureza sobretudo ficcional (Belmont 1986). Como esclarece significativamente Seu Casemiro, o narrador da versão 4 ouvida de seu avô em 1935, a história relatada é "de antigamente", de uma brincadeira em um "sistema" que já não era mais e, provavelmente, nunca foi tal e qual narrado.

De todo modo, um universo narrativo específico e atuante, para cuja natureza vale atentar, desenvolveu-se pouco a pouco em torno do folguedo. São relatos orais, ou sínteses deles, registrados por pesquisadores (versões $5,6,7,9)$; relatos em que os próprios pesquisadores se atribuem o papel de narradores (versões 1 e 2); relatos escritos por brincantes e entregues a pesquisadores (Versões 4 e 8); toadas que tematizam aspectos desses relatos (versão 3). Trata-se então de buscar outro plano analítico para a compreensão dessas narrativas de origem do folguedo que articulam em torno do boi que morre e ressuscita um conjunto altamente sistemático de relações e ações padronizadas. Proponho sua análise como um mito na acepção estrutural do termo.

\section{Um mito do boi: exercício de análise estrutural}

Ne jamais chercher la version originelle, noter toutes les versions.

(Mauss 1967:252)

O caráter sistemático, a constância de temas e a recorrência das ações nesse universo narrativo impuseram-se lentamente à reflexão. Certamente não se trata, como vimos, de reivindicar uma relação direta de espelhamento entre 
"mito" e "rito". Entretanto, como lidamos com processos culturais cujos múltiplos níveis guardam algum tipo de coerência, "expressões de uma atividade mental organizada" (Vernant 1999), parece razoável supor que há formas de ligação entre essas narrativas e os diferentes tipos do folguedo do boi.

Tomando então os relatos como objetos em si mesmos, proponho sua análise estrutural. Amparo-me nas conhecidas formulações de Lévi-Strauss, cuja natureza problemática tem a vantagem de delimitar com clareza o plano e os pressupostos dessa investida analítica. Destaco a idéia de que "a substância do mito não se encontra nem no estilo, nem no modo de narração, nem na sintaxe, mas na história que é relatada" (Lévi-Strauss 1967:242). Essa história fundamenta a base lingüística, operando em um plano metalingüístico, através da qual um certo "problema" é proposto à reflexão coletiva. Mantenho viva, entretanto, outra idéia, que amplia e relativiza essa primeira: a de que "mito" e "rito" podem integrar um mesmo sistema, visível aqui e acolá se, renunciando à busca de causalidades mecânicas, concebermos suas relações "no plano de uma dialética, acessível somente sob a condição de ter previamente reduzido ambos a seus elementos estruturais" (Lévi-Strauss 1967:268) ${ }^{21}$.

Todos esses relatos aludem a, ou têm como finalidade explícita indicar um "começo" cujos termos configuram um ativo sistema de relações. Narrativas de origem, portanto, cuja natureza mítica como criações coletivas sujeitas à coerção de regras inconscientes trata-se de demonstrar.

Elegi a concisa variante sumarizada por Bordallo da Silva (1981:51) (Versão 1) como versão de referência. Proponho sua análise, à qual incorporo os elementos das demais variantes, em três seqüências que guardam a ordenação das fases de um rito de passagem (Van Gennep 1978): separação, liminaridade, reagregação ou aquelas de um drama social (Turner 1957,1971) com a crise provocada pela ruptura da regra social, reparação e reintegração (ou cisma) ${ }^{22}$. Sigo o método proposto por Lévi Strauss (1967:237-265; 1993:152-205), desdobrando as narrativas em mitemas, seqüências e códigos, trabalhando nos planos sintagmático e paradigmático.

\section{III.1 Primeira seqüência: situação e separação}

\section{Fazendeiro presenteia filha com o Boi.}

Por vezes, o fazendeiro apenas tem o boi (5 e 6); ou então o boi é adquirido para a esposa, "D. Maria" (8).

Atributos do boi: adquirido pelo amo, "famoso pelas suas qualidades e valentia" (versão 1); "o touro mais bonito do patrão", "o touro de raça", "o touro de fama" (versão 2); o "Boi Barroso", "de propriedade de um certo 
senhor" (versão 5); "um belo touro chamado Barroso", "o mimo da fazenda", "sabia dançar", "o agrado dos olhos do senhor" (versão 6); o dono "não mediu esforços para a aquisição", "um presente de muito mimo e carinho para o natalício de sua estimada esposa, o estimado, o lindo boi, que era a menina de seus olhos" (versão 8); "o boi mais bonito da fazenda" (versão 9).

\section{Esquema diacrônico do primeiro mitema}

Esquema sincrônico do primeiro mitema

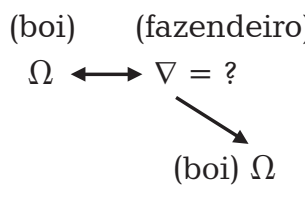

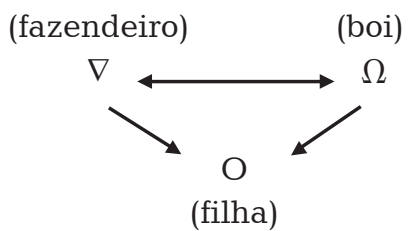

(filha)

(filha) $\mathrm{O}=$ ?

1.A Iniciando a leitura sintagmática, o boi vincula gerações diferenciadas e sexos opostos ligados por laços de descendência dentro do grupo doméstico. Há um pai que já reproduziu (pater e genitor) e uma filha (supostamente virgem, ou ao menos certamente solteira) que irá reproduzir. Pai e filha estão ligados entre si por "um boi especial, um boi reprodutor". O boi é riqueza, mas de que riqueza exatamente se trata? O tema da reprodução emerge bastante acentuado, pois essa primeira tríade alinha-se pelo código sexual que aproxima o humano do animal, ao ligar o fazendeiro (pater + genitor / falo humano cuja potência já foi realizada ou comprovada) ao boi reprodutor (equivalente animal do genitor humano / falo animal, potência em estado bruto) e à filha (reprodutora feminina / ventre humano a ser fecundado). A cadeia semântica associada ao pólo masculino dominante desdobra-se em macho, genitor, pater, criador, protetor, mando e riqueza social, falo; e ao pólo feminino subsumido associam-se fêmea, virgem, futura genitora, ventre, protegida, obediência, riqueza social derivada.

No código sociológico, o tema da aliança, da continuidade do grupo social insinua-se, indicando que o boi especial, capaz de gerar e expandir a riqueza do fazendeiro, é dado à filha como futuro dote. O noivo de sinhazinha (provavelmente oriundo de uma outra fazenda) ${ }^{23}$ é, entretanto, ausência diante da qual o dote sinaliza proximidade excessiva e presença velada do tema do incesto. Presente prematuro, sem noivo à vista, que opera uma quase fecundação simbólica da filha pelo pai (o "boi" leva mentalmente o falo do pai ao ventre da filha, hipótese que parece reforçar-se com a versão 8 em que o boi é dado à esposa D. Maria, em seu "natalício"). De todo modo, mesmo sem ir tão longe, a riqueza social e a capacidade reprodutiva humana 
ligam-se e são pensadas através do boi, e a filha não pode permanecer como termo final do destino do boi. A narrativa imediatamente devolve o boi ao fazendeiro, em um curioso movimento para dentro do universo relacional inicial: ao invés de abrir-se para fora da fazenda, ou seja, ao encontro de outras fazendas (como sugere a idéia vislumbrada do boi como dote), a história prosseguirá para dentro e para baixo na escala social. O boi será entregue aos cuidados de um vaqueiro, como o boi, especial.

1.B. Em uma leitura sincrônica, a associação do fazendeiro ao boi é simultaneamente metonímica e metafórica: "o fazendeiro possui o boi" e "o fazendeiro é potente como o boi". A contigüidade aproxima, distinguindo entretanto o humano do animal pela relação de posse; a metáfora compara, enfocando uma característica comum a ambos: potência, capacidade de reprodução física, tornando homólogas as posições do boi e do fazendeiro em seus distintos reinos $^{24}$. Essa correlação produz o efeito de uma inversão hierárquica (Dumont 1970) pois, se no plano sociológico o humano engloba o animal, o termo mais amplo é o animal que, como potência física e reprodutiva, engloba o humano. Essa inversão introduz a dimensão cósmica e transcendente na narrativa: uma riqueza de outra natureza, o tema da geração de vida no sentido mais amplo. Se a potência e a reprodução físicas associam-se em um primeiro momento à riqueza social, isso é pouco e injusto. Na seqüência narrativa, logo os temas da potência e da reprodução transbordarão seu continente sociológico.

Ainda nessa equação, se a relação entre filha e pai é metonímica, de descendência, a relação entre filha e boi é também metafórica. A filha é, em certo sentido, como o boi pois, assim como o fazendeiro possui o boi, ele também "possui" a filha, englobada no interior desse primeiro grupo doméstico e destinada à aliança futura.

1.C. Superpondo as duas chaves de leitura, percebemos um movimento centrífugo: pai possui filha que possui boi, ambos destinados à reprodução e, como no código sociológico o humano engloba o animal, o boi-dote é parte da filha rumo à troca matrimonial futura. Há, entretanto, também um movimento centrípeto, que prevalecerá na seqüência narrativa, pois temos: o pai que comprou o boi que doou à filha que ainda pertence ao pai. O pai é potente como o boi, (como potente também deverá ser o futuro marido da filha) pois, como o boi que procriará, ele já procriou. A filha é análoga por inversões ao boi (masculino/falo x feminino/ventre + humano $\mathrm{x}$ animal) porque, como ele, seu destino é a troca, mas diferentemente dele será o receptáculo da potência reprodutiva. O boi, ligação entre pai e filha, reúne a mesma qualidade animal do pai, a potência, e a mesma qualidade humana da filha, a submissão. 


\section{Fazendeiro confia boi ao vaqueiro}

Atributos do vaqueiro: empregado especial, excetuando a versão 8 em que Pai Francisco é parte de um grupo de moradores livres de "terra distante", porém contígua ao pasto da fazenda, "uma família bastante conhecida e de péssimos costumes, composta de um velho que se chamava Pai Francisco, sua mulher Catirina, seu compadre Cazumbá e Mãe Guimá". Nas versões 2, 5 e 6, é "empregado da fazenda", "do patrão" ou "do senhor". Na versão 4, é escravo de um "coronelão". Na 9, é "o capataz da fazenda".

\section{Esquema do segundo mitema:}

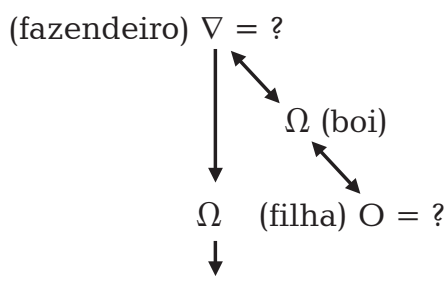

(vaqueiro) $\nabla=$ ?

A doação do boi, contudo, parece ser precipitada (ventre a ser fecundado em troca matrimonial desejável) ou talvez prenúncio de transgressão (ventre indevidamente fecundado em relação incestuosa). Fato é que o destino do boi como dote não se efetiva e qualquer transgressão sugerida é silenciada. O ventre de sinhazinha é deixado de lado, porém, a dádiva do fazendeiro permanece contida no interior do próprio grupo doméstico. Imediatamente, o fazendeiro retoma o boi para si, entregando-o ao vaqueiro. Não a um vaqueiro (empregado ou escravo) qualquer, mas de sua especial confiança, individualizado em um nome próprio e categórico - Pai Francisco, "nêgo Chico"25. Verdadeiro herói dessa história pois, não sendo o boi especial mediador suficientemente capaz de equilibrar e garantir a abertura desse microuniverso, será ele, o vaqueiro especial, o personagem convocado a promover essa impossível tarefa. De imediato, na nominação do vaqueiro sobressai a qualidade humana que o associa ao fazendeiro; como este, Francisco é Pai.

O vaqueiro é Pai metafísico, ontológico. Com ele, a condição sociológica de empregado e dependente do patrão é englobada por um valor transcendente. Pai Francisco e boi, ambos possuídos pelo fazendeiro, opõem-se complementarmente. Se o boi terminava por englobar o fazendeiro pelo aspecto animal da potência reprodutiva, Pai Francisco engloba o boi, domesticando-o por um valor social e cultural por excelência: Pai. Possuindo a posse de seu possuidor, "nêgo" Chico encarna um atributo cultural do ser masculino: é não apenas genitor, mas pater. Latência. 
Com essa operação, um valor social supremo, a paternidade, anunciada desde o início pelo personagem do fazendeiro, vem se alocar em seu estado puro, "Pai", no baixo social (Turner 2005 [1967]; DaMatta 2000). Não é à toa que Pai Francisco (na versão 4 "um tanto grotesco e caricato") é personagem que, no rito, pertence à linhagem dos palhaços: é bêbado, safado, surrado, eternamente castigado, ou um "missionado", no entender de Seu Betinho, o Pai Francisco narrador das histórias analisadas por Carvalho (2005).

De todo modo, nessa nova passagem do boi, o anunciado atributo da paternidade do vaqueiro permanece por um momento suspenso e emerge do código sociológico. É afirmação de laço de confiança entre patrão e empregado e de laço de lealdade entre este e aquele. Duas das versões selecionadas - a $\mathrm{n}^{\circ} 6$ (a matança de Leonardo) e a $\mathrm{n}^{\circ} 7$ (a "matança do vaqueiro fiel", de Seu Betinho) - dialogam fortemente entre si, elaborando detidamente o complexo confiança-lealdade-traição-mando-subordinação entre vaqueiro e patrão.

A riqueza lógica do boi, até agora verdadeiro dínamo dessa narrativa, é notável: mediador entre pai / homem / mais velho / descendência já assegurada e filha / mulher / mais jovem / a ser trocada; e entre o alto social / branco / patrão e o baixo social / negro / empregado. Entregue aos cuidados do vaqueiro, o boi estaciona por um momento em seu destino animal, e vira termo em uma espécie de mitema oculto: Vaqueiro cuida do boi.

O vaqueiro, por sua vez, entrou em cena, ele mesmo, como elemento de mediação entre a casa grande, a morada do fazendeiro e da filha, e um novo espaço surgido dentro da fazenda: o pasto destinado ao gado. Transitando entre um mundo e outro, ele deve, de certo modo, lealdade a ambos. No pasto, a lealdade ao patrão transforma-se em lealdade ao boi. Boi, cabe lembrar, reprodutor que, posto sob os cuidados do vaqueiro, sai da confusa situação de mediador interposto entre pai e filha, na qual parecia acentuar perigosamente a sua proximidade.

No pasto, com o vaqueiro e o boi, estamos longe do equilíbrio e em uma situação como que pré-liminar. Há a arriscada conjunção entre humano e animal (DaMatta 1973) e a versão 3, a bela toada de Papete, exprime essa identificação do vaqueiro com o boi, não como propriedade do fazendeiro, mas como um ser pleno que dele depende. É um lamento triste em que o vaqueiro canta sua "dor de ver / o meu boi indo me olhar, e sem nada saber, sem se defender/ chora meu boi...".

Logo um terceiro elemento, a esposa do vaqueiro, entra em cena separando tão dramática quanto problematicamente o vaqueiro de seu boi, e do amo de todos, o fazendeiro. Mãe Catirina, a "Catirina que só quer comer da língua do boi", Mãe cosmológica, porvir e gestação. Fêmea-Mãe, grotesca e 
liminar, fecundidade em estado puro, ventre pleno, promessa de vida futura. Por meio dela, o vaqueiro/macho atualiza a condição latente de genitor e (possível) pater, condições até então pertencentes ao fazendeiro e, simbolizadas pela posse do boi, transferidas aos cuidados do vaqueiro. Catirina é personagem fortemente perturbador, pertencente no rito à linhagem dos palhaços. As ambivalências de toda a série de relações até então expostas acentuam-se de modo dilacerante com a sua entrada em cena, estatelandose em conflito insolúvel.

\section{Esposa grávida do vaqueiro deseja comer a língua do boi.}

Variações: a língua (versões 2, 3, 4, 7); o fígado (versões 5, 9) ; o filé (versão 8). Na versão 7, o desejo é da filha do fazendeiro que "namorou" o vaqueiro.

Atributos de Catirina: Mulher grávida e desejante em todas; arredia e preguiçosa (versão 3); "mulata de beleza falada e cantada na região" (versão 8); " cozinheira mulata" (versão 4).

Em um plano, o vaqueiro é análogo ao boi, podendo substituí-lo em um nível oculto do primeiro mitema "Fazendeiro possui vaqueiro" como possui o boi. A primeira tríade de relações, fazendeiro/boi/filha, foi logo trocada pela segunda, fazendeiro/boi/vaqueiro. No pasto, a dependência do bicho em relação ao vaqueiro toma o lugar da dependência do vaqueiro em relação ao amo e, por sua vez, a lealdade do vaqueiro ao bicho substitui a sua lealdade ao amo. O boi, assim, fica no lugar do patrão, com curiosa inversão da relação de força em que o vaqueiro agora é o pólo dominante.

Nessa mito-lógica, a contigüidade entre os elementos da narrativa acarreta sempre contágio de alguma qualidade do primeiro para o segundo termo. Quando afastados por um mediador, o segundo termo guarda consigo a qualidade do primeiro. Assim, é possível dizer "o fazendeiro é potente como o boi vivo" e "o boi vivo, entregue aos cuidados do vaqueiro, é a potência reprodutiva do fazendeiro" e "o vaqueiro é potente como o fazendeiro (e o boi) ". Em seu percurso narrativo, o boi significa: 1. riqueza social e potência física do amo; 2. garantia de troca matrimonial da filha com um outro universo de fazendas, de relacionamento entre "iguais" na hierarquia social; 3. latência: potência em estado animal; 4. confiança e lealdade entre superior e inferior, elementos de camadas social e economicamente desiguais. $\mathrm{O}$ boi entregue aos cuidados de Pai Francisco é boi pletora, portador de todos esses atributos. Parece razoável então que quem atualize a sugestão de riqueza reprodutiva e a latência da potência física, tão fortemente sugeridas na narrativa, seja Pai Francisco, que será obrigado a "doar" o boi à sua esposa: Mãe Catirina está grávida. A riqueza vital, cósmica e reprodutiva aloca-se no baixo social, todavia, de modo paradoxal. Catirina, grande 
força disruptiva, afirma a humanidade do vaqueiro de modo terrivelmente problemático: submete-o a executor de seu desejo, o desejo de uma mulher grávida, desejo quase supra-humano que se não realizado comprometeria a própria reprodução/potência do vaqueiro. Em um detalhe extraordinário, comentado por um dos narradores na versão 5, Catirina aborta quando o boi ressuscita, "pois Chico, embora furtasse o boi, não chegava a cortar-lhe a língua". Há outro aspecto a ser observado. A conjunção entre vaqueiro e boi no pasto, sugerindo um domínio limítrofe e a confusão entre humano e animal (versão 3) é separada por um elemento (Mãe Catirina), que significativamente vem reforçar a confusão de domínios pelo próprio estado liminar em que se encontra (gravidez = dois em um só), acentuando a dimensão animal inerente à procriação. Há excesso potencialmente transgressor na expressão do desejo incontido que urge atender a qualquer custo. Terrível pedido que é impasse dilacerante para Pai Francisco. "Esta conversa" - nos conta a versão 4 - "levou Pai Francisco ao abismo".

traição ao boi e ao patrão versus "traição" a Catirina e ao feto

$\Omega \neq \nabla \neq \quad(\mathrm{O}+\alpha)$

Se voltarmos agora ao começo da narrativa, na situação liminar da gravidez de Catirina perceberemos a inversão simétrica da situação inicial: $($ Fazendeiro Branco $)=($ Pai potente, tem o boi e a filha, ambos visando à aliança, à reprodução humana prometida através de troca futura) versus (Empregada preta) $=$ (Mãe em latência que, ao contrário do fazendeiro, consome o boi para ter o filho. Mulher grávida que assegura a reprodução mediante consumo imediato de alimento).

Mãe Catirina consome, por assim dizer, o falo do fazendeiro/do boi/do marido, em um desejo incontrolado que, por mais animal que seja, não deixa de ser também expressão de sentimentos sociais negativos. A inveja e a cobiça acarretam um furto e um "crime" que terminam por castrar, de certo modo, a condição humana e sociológica de seu próprio marido. Com a morte sem ressurreição do boi, como na versão 4, Pai Francisco será para sempre humilhado e ofendido, eternamente castigado, surrado, batido: “Bate palma e bate pé, foi Pai Francisco quem matou o boi do coronel, por causa da mulher!".

O boi desejado por Catirina é o predileto do patrão, o boi destinado à troca social, promessa futura abortada para que Catirina, ela mesma, não aborte. O boi - mediador entre o alto e o baixo social internos à fazenda e, em um futuro sugerido, mediador entre a fazenda (o dentro) e o mundo social abrangente (o fora) - é eliminado. O desejo de Catirina consumiu-o, trans- 
formou-o em alimento compartilhado entre limites estreitos (imediatamente ingerido por ela, ou por ela e por seu marido, visto "comendo carne assada" na versão 4). Diante da aliança futura da família rica, Catirina é revolta e afirmação da premência em assegurar a descendência de sua própria família pobre, tornada assim anti-social.

A dificuldade de Pai Francisco em garantir um lugar para sua hombridade é dramática: ou instrumento do fazendeiro a serviço da continuidade da descendência deste, ou instrumento da mulher para alcançar a sua própria descendência. Não é à toa que na descrição de Ascenso Ferreira (1944), na seqüência dramática do boi, quando ele cai morto, flechado por um caboclo brabo, entoa-se a toada do funeral e faz-se na audiência silêncio profundo.

\section{Vaqueiro mata o boi}

(Versões 1, 2, 3, 4, 5, 6, 8). Variações: "só puxou a língua dele e cortou e fez" (versão 9)

A morte do boi é um "fim de mundo". É também sacrifício paradoxal, morte ofertada para que o casal pobre possa se reproduzir, para que o casal socialmente pobre seja vitalmente rico. Porém sacrifício que, ao ser executado por Pai Francisco visando garantir a vida de seu filho, destrói o sistema de vinculações do mundo da fazenda. Tudo começou com o boi articulando reprodução biológica à riqueza e à reprodução social, definindo a masculinidade plena pela conjunção, no personagem do fazendeiro, entre pater e genitor. O boi era também o propulsor do próprio movimento narrativo: força, poder, potência, dinamizador e dínamo a um só tempo. Sua morte é tremendamente ambivalente: é crime (consumo indevido, destruição do bem alheio), mas é também sacrifício legítimo (vida animal em troca de vida humana, vida do boi em troca da vida do filho do casal pobre). No segundo mitema, o boi é confiança do patrão no empregado, é lealdade do empregado para com o patrão. Sua morte é crise total no sistema de mediações da fazenda. A primeira seqüência narrativa termina aniquilando o universo auto-contido da fazenda. O segundo mediador proposto, o vaqueiro, ao aniquilar o primeiro mediador se auto-aniquila, o universo relacional rompe-se em extremos.

\section{III.2. Intervalo. Interpretação sociológica conversando com DaMatta}

A narrativa inicia-se em um espaço moral e socialmente denso e inquieto. A fazenda mítica é pletora de gestos que nos precipitam, em um piscar de olhos, em um desfecho trágico: o boi querido, que acabamos de conhecer, 
morreu. A primeira seqüência apresenta excessivo dinamismo desequilibrado. O conjunto de relações e inversões anuncia o tema central: a vida e a morte do bicho precioso, desdobrado no seguinte feixe de oposições: vida do boi $($ boi + ), elemento assegurador de troca coletiva = riqueza social / dádiva, riqueza vital e reprodutiva / confiança / potência masculina versus morte do boi (boi -) = riqueza social ameaçada / pobreza / inveja / traição / fecundidade feminina (boi tornado alimento e imediatamente consumido, rompimento da troca social ampla).

O mundo da fazenda é autocentrado, os meios de reprodução e produção estão, a princípio, todos lá, a dependência entre rico e pobre é claramente afirmada. Estamos em pleno universo moral da patronagem, no qual a oposição proprietário/trabalhador é pensada como complementaridade em uma teia de relações cheia de compensações. Há respeito do patrão pelo empregado, com a demonstração de apreço e distinção que o pedido especial do fazendeiro ao vaqueiro também especial explicita. Do lado de Pai Francisco estão sugeridas a lealdade e a submissão devidas. Firmada através do boi, a relação empregado/patrão significa ascendência/submissão, autoridade/obediência, confiança/lealdade - pares relacionais propostos como modelo ideal. O fazendeiro desse primeiro momento é um bom patrão, ao contrário do patrão explorador que chega a "tirar o couro" de seus empregados, como no conto de Pedro Malasartes (DaMatta 1979:194-235). Porém, assim como em Malasartes, há desequilíbrios básicos que a situação inicial contém momentaneamente. Com a transgressão do vaqueiro, algumas versões revelarão sem maiores pruridos a possível crueldade do patrão: Pai Francisco é ameaçado de castigo na versão 1; na versão 4 "o coronel mandou botar de castigo, prometeu-lhe mandar cortar o pescoço" (e o castiga todo ano doravante, pelo gosto de ver "como ele ficava zangado" [...]); surrado na versão 5; aguardando o castigo, na versão 6 . A patronagem com a estima e a consideração características e a contra-face violenta ou rebelde emerge como dado da realidade masculina.

A essa complementaridade hierárquica da patronagem sobrepõe-se, contudo, uma problemática igualdade. Riqueza e pobreza são apresentadas como categorias não apenas complementares, mas também abertas e extremamente conflitivas, pois os dois grupos domésticos são ricos do ponto de vista vital e demográfico. O ciclo de desenvolvimento de ambos está em plena produtividade sexual e social, com um lapso de tempo entre um e outro. Se o fazendeiro tem uma filha, Pai Francisco tem um filho por nascer. A família surge como valor fundamental nos dois extremos sociais. Essa riqueza vital afirma-se por entre grandes desequilíbrios. Se está implícito que a filha do fazendeiro é bela, solteira, obediente e casadoira, a gravidez de Catirina explicita-se de modo despudorado. 
A relação entre os dois homens mais fortes na história é de dominação e submissão, mas é também de grande dependência moral: são ambos chefes de família. Talvez por isso, quando depois da crise a narrativa começa o seu movimento de reversão, o fazendeiro no fundo entenda as razões de Pai Francisco, dando-lhe a "chance" de ressuscitar o Boi. Afinal, foi tudo "por causa da mulher"... A questão-chave é: como assegurar a reprodução social nesse universo fechado? A aparente harmonia encobre conflitos latentes, que irrompem com força disruptiva com o desejo de Catirina. Com ele, o pacto de lealdade firmado entre os dois homens através do boi rompe-se. Afinal, se o fazendeiro com a filha e o touro reprodutor afirmam a capacidade de transformar um laço de substância em afinidade, o par Pai Francisco e Mãe Catirina é apresentado em terrível luta para transformar a aliança em descendência (Abreu 1983). Sua sexualidade, vista como assegurada (embora excessiva, no pólo feminino, a falta de pudor de Catirina desejosa e preguiçosa), precisa ainda garantir a reprodução efetiva.

Nos dois casos - no segundo casal de modo premente, mas também no primeiro casal da elite - há esforço de abertura narrativa para aqueles que virão: o marido de sinhazinha e o filho de pai Francisco. Sem esse duplo futuro, o universo complementar tenso e autocentrado da fazenda está em crise total. Os dois grupos são potencialmente ricos em sua capacidade de reproduzir. A conciliação entre a riqueza vital dos dois grupos, que pede a equiparação entre riqueza social e vital, é o problema que permanece não resolvido e sempre proposto pelo mito.

\section{III.3. Liminaridade e reagregação. Segunda e terceira seqüências}

\section{Segunda seqüência: no mato e de volta à fazenda}

5. Fazendeiro busca boi e descobre o crime

6. Vaqueiros fracassam em capturar Pai Francisco

7. Índios capturam Pai Francisco

8. Fazendeiro pune / ameaça punir Pai Francisco

Essa seqüência é movimentadíssima, com idas e vindas entre fazenda, pasto e mato. Porém, do ponto de vista estritamente narrativo, não é tão densa quanto a primeira, exceto pela abertura do sistema relacional da fazenda e pelo alargamento da geografia humana da narrativa. Surge o habitante do "mato": o índio. Em alguns casos (versão 8), é o "diretor dos índios" ou o "tuxaua" e o "pajé" da tribo que aparecem como os senhores da mata e das fronteiras, e emergem como candidatos a mediadores entre um universo conhecido e outro desconhecido. A narrativa inicia sua reversão, retornando 
à fazenda, ao ponto espacial de partida, com uma ausência fundamental: o boi. Ausência que configura também uma inversão, pois no começo tínhamos, via boi, promessa de vida, e agora temos a sua morte a obscurecer inteiramente a garantia de vida do feto de Catirina. Morte, falta terrível que acelera o movimento narrativo em busca daquela vida que garantia a continuidade de toda vida.

Na sua ausência, a reintegração de Pai Francisco à fazenda é violenta também, apresentando a outra face da patronagem através da nova situação em que se enfrentam os mesmos personagens: Pai Francisco é surrado, castigado, tiram-lhe o couro das costas, amarram-no diante de uma fogueira e a punição pode durar eternamente. A falta do boi é começo ativo de busca: fazendeiro busca o boi, vaqueiros buscam Pai Francisco, vaqueiros buscam índios, índios buscam Pai Francisco finalmente capturado. A reversão espacial - todos, inclusive os índios, retornam à fazenda - corresponde a um processo de reversão temporal e reversão também nos outros códigos narrativos:

Mato versus fazenda :: Liminar versus centro :: Baixo social versus alto social :: Morte versus Vida.

\section{Terceira seqüência: da fazenda à festa}

8. Fazendeiro condiciona perdão de Pai Francisco à ressurreição do boi 9. Vaqueiro chama médico / vaqueiro chama padre / vaqueiro chama pajé. 10. Boi ressuscita em festa

Médico, padre ou pajé são, cada um a seu modo, mediadores entre este e um outro mundo, são operadores de passagens entre o mundo do além e o daqui. Na narrativa, esses personagens interpõem-se entre fazendeiro e vaqueiro no esforço de suavizar o terrível conflito explicitado: a reprodução do senhor nega a do escravo/trabalhador ou vice-versa. Universo impossível, complementaridade transformada em antagonismo puro, no qual a sobrevivência e a continuidade de um dos termos é a destruição do outro. Suavizando o confronto rico $\mathrm{x}$ pobre, lealdade $\mathrm{x}$ traição, médico, padre e pajé buscam devolver ao universo descrito o seu mediador essencial: o boi. Todos tentam e terminam por realizar o impossível: ressuscitar o boi. O boi deve agora concretizar novo trânsito, retornando da morte para a vida. Por que a imaginação o ressuscita?

\section{Do mito ao rito}

Começo observando a presença de personagens paradigmáticos da história nacional nesse universo narrativo, como o médico e o padre cuja importância 
para as transformações da sociedade patriarcal foram tão bem assinaladas por Gilberto Freyre (1977); ou como o pajé, secundado de "caboclos brabos", personagem que parece também integrar-se na cultura popular ao longo do século XIX (Boyer 1999). É notória a forte evocação do ciclo econômico do gado, com a fazenda, os animais, os vaqueiros e o pastos; e da escravidão, com os protagonistas Pai Francisco e Mãe Catirina. Vale assinalar também a recorrente utilização pela narrativa dos três tipos "étnicos" protagonistas da "fábula das três raças" na já célebre análise de DaMatta (1987) ${ }^{26}$. Aqui, porém, ao contrário do que ocorre nas versões mais comuns da dita fábula, apresenta-se uma visão mais ambivalente e fortemente crítica com relação à dominação e às hierarquias expressando a precariedade da ordem social.

Nessa conclusão, porém, mais do que explicar a origem histórica do folguedo ou explorar as dimensões sociológicas já evocadas assinalo apenas o fértil uso simbólico dessas dimensões da sociedade brasileira. Mantenho o enfoque analítico no exame das narrativas em si e com elas caminho rumo ao rito. Pois vale observar que a partir da morte do boi, isto é, na passagem da primeira para a segunda seqüência, as narrativas examinadas vão desaguando no rito e na festa. Explico-me: o momento narrativo da morte do boi pertence à narrativa da origem propriamente dita, mas desde dentro dela refere-se a uma nova dimensão da realidade, ao momento ritual da encenação festiva. A idéia narrativa da morte do boi propicia a conexão mental direta com o momento ritual em que o boi-artefato precisa sumir de cena, precisa morrer (esvaziar-se da "tripa" ou do "miolo" humano). O esforço de cura do boi, e da sociedade doente que ele simboliza, é assunto privilegiado para performances cômicas em elaborações rituais festivas. Seguindo essa linha de raciocínio, observo que, em especial, o momento narrativo final da ressurreição do boi corresponde à transposição plena da temporalidade da "origem" para o "aqui e agora" de uma situação festiva: "O acontecimento é festejado com extrema alegria, e o bando, sempre cantando, 'dá a despedida'" (versão 1).

Na versão 2: "o boi revivia e aí a alegria de todos, começava de novo a cantoria e todo mundo festejava a ressurreição do boi (...)". Versão 6: "Urrou! Urrou!/Urrou que ouvi!/Boi mais bonito que este / Garanto que nunca vi!/Urrou! Urrou!/Urrou fama reá! / Boi de fama como este / No sertão não haverá. Era o perdão de Chico, era a cantoria, era a festa". Versão 8: "O Pai Francisco aplicou tudo o que lhe foi ensinado a fazer. É quando se nota que o boi quer se levantar, pois nesta altura é mandado por debaixo do mesmo um homem conhecido por tripa. Nego Chico faz a entrega de sua espingarda ao fazendeiro. Respondem os restantes 'Levantou bumbá/ levantou pra vim brincar (bis)'". 
A morte e a ressurreição do boi correspondem à própria abertura da narrativa para outro nível de realidade, novo tempo e novo espaço. Com elas, saímos do mundo ficcional da fazenda e de seus arredores e chegamos ao local real de realização de uma brincadeira: o "aqui e agora" de um pátio, uma rua, uma arena, um tablado, um terreiro. A temporalidade enclausurada da narrativa deságua no rito. Mais uma vez, o mediador dessa operação simbólica eficaz é o boi. Nesses momentos críticos, justapõem-se o boi precioso da história e o boi-artefato bailante. Passamos, assim, no mesmo processo mental, do mito ao rito.

A ressurreição do boi metaforiza a própria festa e sua razão de ser. O boi permanece, então, até o final de nossa história, como o portador de grande potencial vital e complicador. Há nas narrativas analisadas a presença de um "depois" do drama que sugere a construção de uma nova ordem de existência. O boi que ressuscita é rito e, com ele, o drama mítico abre-se para novos códigos de sentido. É festa com sua ampla comensalidade e sociabilidade: todos devem comer a carne do boi. Os próprios atos humanos inscrevem-se em uma vasta rede de reciprocidade estabelecida com os santos juninos. Um boi é "promessa" feita ao santo (Lanna 1995). Seu Betinho, o narrador central na tese de Carvalho (2005), bem expressou essa dimensão profunda de construção da pessoa dos brincantes em sua visão do exercício da função de Pai Francisco como uma missão ${ }^{27}$.

Há também um novo código temporal, a temporalidade cíclica e repetitiva dos ritos. Realizar o bumbá é recomeçar, ressuscitando o boi que deve sempre voltar para brincar em um novo ano. Em uma chave sociológica, poderíamos ler no folguedo a sátira e a crítica às múltiplas dependências da ordem social em um país pós-escravocrata em busca de cidadania. Nesse caso, as "narrativas do auto" poderiam ser entendidas como uma espécie de mito de origem, e o folguedo traria justamente consigo a repetida busca por uma nova sociedade. A morte do boi, afinal, impõe aberturas ao mundo da "fazenda", trazendo o médico, o padre, o pajé. A ordem anterior é radicalmente modificada, nada será como antes depois da perda do boi. No rito, o fazendeiro da narrativa, o amo do boi ou o cabeceira na performance é servo de seu grupo de boi. Nas performances associadas ao drama há também distância dramática entre ator e personagem, há espaço para o riso grotesco. Afinal, Pai Francisco e Mãe Catirina são palhaços que, contracenando com o amo, abordam áreas críticas da vida social em sua atuação cômica ${ }^{28}$.

Essas narrativas também configuram, no entanto, um mito de origem em uma acepção estrutural plena (Lévi-Strauss 1976:250-279). A narração contemporânea desse drama corresponde à ativação presente de forças simbólicas. Através dele, o rito - brincadeira anual repetitiva - ao mesmo 
TEMA E VARIANTES DO MITO: SOBRE A MORTE E A RESSURREIÇÃO DO BOI

tempo em que atualiza um suposto passado marca fortemente sua diferença com o presente, como se o curso da história em sua dimensão diacrônica fosse reconhecido pelo folguedo com essa pura distinção entre passado e presente. A idéia tão encantadora da "origem" parece ter sobretudo a função ritual de demarcar duas formas básicas da temporalidade diacrônica: o presente que é devir diante de um passado que é sempre o mesmo. O Boi da narrativa tem a função de um churinga (Lévi-Strauss 1976:272-277), "o ser diacrônico da diacronia dentro da própria sincronia". Ao passo que o boi-artefato, ao qual ele se acopla na morte e na ressurreição, é ingresso na diacronia, abertura para a história. A ressurreição do boi é passagem de um registro temporal para outro. Se assim é, entre a morte e o "urrou" há uma inexistência profundamente perigosa: hora de buscas prementes. Tudo pode vir a não ser. Não só a não ser como antes, porque depois da ressurreição do bicho nada será igual novamente, mas simplesmente não ser. Nossa narrativa mítica expressa assim, como propôs Lévi Strauss (1976:278-279), os caracteres fundamentais do acontecimento histórico: sua contingência - foi em uma fazenda e não em outro lugar qualquer, aconteceu desse jeito e não de outro qualquer, fez-se isso e aquilo e o resultado foi esse - e seu poder de suscitar emoções intensas e variadas.

O boi mítico que morreu transformou-se em alimento vivo a ser compartilhado pelo grupo, trazendo para o centro da cena um plano analítico inteiramente novo, o rito com sua dimensão afetiva e cognitiva plena (Valeri 1994). Afinal, a efetiva abertura do universo da fazenda mítica rumo à troca social ampla concretiza-se no rito e, mais uma vez, o operador dessa nova passagem é o boi, tornado agora emblema dos grupos brincantes. Se no mito tratamos sempre de um boi precioso, na brincadeira esse boi multiplica-se, e a unidade ritual mínima é constituída de pelo menos dois "bois" que rivalizam entre si. A festa não é apenas esforço de conciliação, mas propõe também formas veladas ou abertas de competição. O boi ressurreto é forma puramente simbólica de vida: Bumba-meu-boi! É potência pura, dança ou surra, possibilidade de vinculação.

Recebido em 09 de agosto de 2005

Aprovado em 20 de setembro de 2005

Maria Laura Viveiros de Castro Cavalcanti é professora do Departamento de Antropologia Cultural e do Programa de Pós-Graduação em Sociologia e Antropologia do IFCS/UFRJ. E-mail: <cavalcanti.laura@gmail.com> 


\section{Notas}

1"Brincadeira" é expressão nativa muito usada em vários folguedos brasileiros. O termo assinala, com propriedade, sua dimensão lúdica e festiva. Para enumeração de suas variantes, ver também CNFCP, 2003a.

${ }^{2}$ A pesquisa iniciou-se em Parintins, Amazonas, onde estive em 1996, 1999 e 2004. Em 2000, conheci a brincadeira maranhense durante o período junino em São Luís e orientei a pesquisa de Carvalho (2005), com a qual este texto mantém estreito diálogo. O Centro Nacional de Folclore e Cultura Popular (2003b) realizou também a pesquisa etnográfica do Bumba-meu-boi maranhense coordenada por Luciana Carvalho e Gustavo Pacheco. Para uma discussão da inserção do folguedo nas respectivas sociedades locais, remeto o leitor a Cavalcanti, 2000 para o Bumbá de Parintins e a Carvalho, 2005 para o Bumba-meu-Boi maranhense.

${ }^{3}$ Não cabe aqui resenhar essa extensa literatura, na qual gostaria de destacar a dissertação de Prado (1977). Essas considerações esquemáticas visam apenas situar o plano das indagações propostas.

${ }^{4}$ Alguns estudiosos sugeriram as últimas décadas do século XVIII (Cascudo 1984:150; Andrade 1982:71-73) como período de formação do folguedo. A brincadeira integraria então o processo histórico mais amplo de formação do que hoje conhecemos como folclore ou cultura popular brasileira, cuja base católica já foi assinalada por Abreu (1998). O registro mais antigo que encontrei na pesquisa é uma pequena nota de 7 de julho de 1829 no jornal "O Farol Maranhense", n.104. p. 451 na seção de variedades. Transcrevo: "Sr. Redactor - Moro no Bacanga e poucas vezes venho à cidade. Mas tenho um compadre que me fica visinho, que não passa festa que não venha assistir a ella. Pela de S. João veio elle, só para ver as correrias do Bumba-meu-boi, e na volta contou-me as seguintes novidades que por duvidar um pouco déllas, tencionei contar-lhas para me fazer o favor de dizer si são ou não verdadeiras. Disse-me o tal meu compadre, que na noite de São João houve muitos fogos: que andavão malocas de 40 e 50 pessoas pelas ruas armados de buscapés, todos mui alegres que a Polícia não prendeo a ninguem por quanto nenhuma desordem acontecera. Ora Sr. redator, que dirão a isto os meus senhores das revoluções? (....) que já não se dão passaportes para o interior da província: que já não se prende a ninguém por ler o Farol: que o cidadão anda alegre, toca, dansa, tudo à sombra das ballas que vem da Fortaleza".

${ }^{5}$ Romero (1954), que via nas festas a poesia popular "em ação", não conferiu especial destaque interpretativo ao "reisado do boi" que conhecia em sua cidade natal, Lagarto, em Sergipe. Pereira da Costa (1908:260), entretanto, comentando o desuso da "folgança" em Pernambuco, referiu-se ao Bumba como uma "rapsódia do Norte, e puramente brazileira, sem afinidades e imitações estranhas". Almeida (1942:52) considerou-o "o folguedo brasileiro de maior significação estética e social". Mesmo Cascudo, sempre avesso à construção de fronteiras culturais nacionais, viu no folguedo uma "criação genial do mestiço" (1984:150). Ou ainda: "O brasileiro, em alegria, sátira, sentimentalismo, piedade, justiça e arbítrio, samba e oração, está no bumba-meu-boi" (Cascudo 1952:454). 
${ }^{6}$ Conforme revelou Lopez (1972), Mário de Andrade foi leitor aplicado de Frazer, Tylor e Lévy-Bruhl. Sobre o primitivismo em Andrade, ver Travassos (1997).

${ }^{7}$ Andrade percebeu também a natureza fragmentária dessa "rapsódia" popular. Porém, mesmo valorizando essa forma de composição estética, a ausência do dito entrecho central em formas então contemporâneas do folguedo ganhou também o sentido de triste sinal da inexorável decadência de nosso folclore (Andrade 1982:5470). A constatação da variedade concreta de formas do bumba-meu-boi, e mesmo de sua fragmentação interna, é recorrente na literatura. Esse outro pólo da percepção da brincadeira sempre provocou reações ambivalentes: "Agregado de disparates", já afirmara em 1840, o mau-humorado Carapuceiro (Lopes Gama 1996:330).

${ }^{8}$ Por sinal, esse mesmo Boi Misterioso de Afogados é objeto de outro registro do "auto" tradicional por Borba Filho (1966). A idéia de um "auto" originário, entretanto, já circulava há muito entre os interessados nas expressões populares. Artur Azevedo (1906:9) comentava: "É mesmo provável que o Bumba meu Boi, na forma primitiva, fosse um auto composto, com todas as regras do gênero, por algum poeta do povo (...) Hoje é um simples folguedo sem significação alguma, exibindo vários personagens cujas funções não estão logicamente determinadas". Certamente a ambivalência do próprio Mário de Andrade em relação ao folguedo, bem como a presença constitutiva da retórica da perda (Gonçalves 1997) nos estudos de folclore exerceram sua pressão nessa direção simplificadora.

${ }^{9}$ As mesmas ressalvas são pertinentes no universo do carnaval, ver Cavalcanti 1994 e 2002a.

${ }^{10}$ Um novo universo dramático, encontrado no interior por Carvalho (2005), livremente relacionado ao tema do boi, não é denominado pelos brincantes de "auto", mas sim de "matanças". A narrativa do "auto", entretanto, ao se aproximar de uma certa visão oficial do folguedo, exerce notória pressão. Em junho de 2000, em São Luís, pude presenciar acentuada preocupação por parte de instituições culturais e turísticas e de intelectuais próximos do bumba com a suposta perda da "tradição de encenação do auto". Carvalho (2005) atestou o mesmo entre 2001 e 2004. Desde 1996, quando comecei a pesquisa, o Bumbá de Parintins assumia para si uma espécie de inautenticidade nessa conversa entre bois quando se "explicava" a partir da narrativa do "auto", que suas performances riquíssimas, entretanto, só encenavam de forma muito enfraquecida. Essa crença foi tão longe que, em 2004, a performance dos dois bois, em uma das três noites do espetáculo (aquela destinada à "tradição" e ao "folclore") trazia um quadro pleno do "auto", acompanhado por uma meta-narrativa do "enredo" proferida pelo apresentador.

${ }^{11}$ Por sinal, a bibliografia já citada traz muitas vezes a ressalva de que esse "núcleo central" ou deixa resíduos não explicados, ou ele mesmo se faz presente de modo difuso, constatando o improviso, a fragmentação e a variedade.

${ }^{12}$ Vernant (2001) chama a atenção para as frouxas fronteiras existentes entre o que chamamos de "crença" e a consciência, por vezes muito clara, da natureza fictícia das coisas em que se "crê". Essa frouxidão parece demarcar o domínio do mito por oposição ao logos, a narrativa baseada na argumentação. 
${ }^{13}$ No prefácio à reedição desse livro, publicado inicialmente em 1951, o autor diria também que "La Tarasque", ela mesma, integrava uma unidade maior, o cristianismo mediterrâneo (Dumont 1987).

${ }^{14}$ Para a existência de outros bichos nas brincadeiras do boi, vale registrar a bela exposição "Os bichos do boi", organizada por Luciana Carvalho e Jandir Gonçalves no Centro Cultural Domingos Vieira Filho, em São Luís do Maranhão, como parte do Tríduo Junino de 2004.

${ }^{15}$ Como, por exemplo, o personagem do amo do boi que, em Parintins, é sempre um talentoso compositor e cantor de toadas e, em alguns sotaques maranhenses, é o "cabeceira", aquele responsável por "tirar" as toadas da apresentação.

${ }^{16}$ Para uma discussão das toadas no Bumbá de Parintins, ver Braga 2001 e Cavalcanti 2002b.

${ }^{17}$ Como no Bumbá de Parintins ou no chamado "sotaque de orquestra" do bumba maranhense .

${ }^{18}$ Não se trata simplesmente de reivindicar a artificialidade de uma "invenção de tradição" (Hobsbawn 2002), mas de assinalar a complexa inventividade de um processo cultural (Sahlins 1999).

${ }^{19}$ Esse universo narrativo, cristalizado no encontro entre oralidade e escrita, não deixa de pertencer a um processo de criação coletiva cuja natureza Jakobson e Bogatyrev (1973) investigaram. Sua conformação, muito provavelmente, guarda laços com toda a tradição oral dos romances do Boi (Matos 2002) e também com as muitas histórias referentes aos negros significativamente simbolizados como Pais João, Mateus, José, Francisco no contexto escravista e pós-escravista, como o caso de "Pai João" (Abreu 2004).

${ }^{20}$ Nessa linha melancólica, vale lembrar o espetáculo "Catirina", encenação do "auto" apresentada, desde 1996, no teatro Artur Azevedo em São Luís. Carvalho (2005:64) comenta sua surpresa ao ouvir da assessora do prefeito de Cajari, na Baixada Maranhense, a seguinte sugestão: "Você quer ver o auto do bumba-meu-boi? Pois aqui você não vai ver. Você conhece o Teatro Artur Azevedo, em São Luís? O auto verdadeiro está lá, o Catirina. Lá é que você vai ver o auto verdadeiro".

${ }^{21} \mathrm{O}$ longo amadurecimento dessa segunda idéia desaguaria, como assinala Détienne (1981), na noção de "mitismo" (Lévi-Strauss 1971).

${ }^{22}$ Reuni em apêndice as demais variantes consideradas.

${ }^{23}$ No Bumbá de Parintins, a "Sinhazinha da fazenda" é um papel ritual sempre ocupado por uma jovem bonita e obrigatoriamente solteira, membro das parentelas da sociedade regional, dado os fortes laços existentes entre Parintins e Manaus.

${ }^{24}$ Para a discussão da metáfora e da metonímia como modalidades básicas do pensamento e da linguagem humanas, ver Jakobson 2003. 
${ }^{25}$ Versões não consideradas aqui conferem outro nome a esse personagem, ou duplicam-no, como nos cavalos-marinhos nordestinos, em Mateus ou Bastião. O fazendeiro e a filha, os personagens do alto da hierarquia social, são curiosamente anônimos e comuns, ao passo que o boi e o vaqueiro são "especiais". Nas performances de Parintins, a sociologia dos personagens reforça as diferenças hierárquicas das narrativas. Tanto "Amo do Boi" como "Sinhazinha da fazenda" são personagens pertencentes a indivíduos ou famílias que gozam de prestígio social. O amo é sempre um afamado compositor, e as sinhazinhas são sempre jovens solteiras pertencentes a famílias importantes.

${ }^{26}$ Como lembra DaMatta (1987), o fato de que os três elementos sociais - branco, negro e indígena - tenham sido importantes no processo de formação da sociedade brasileira é óbvio. Trata-se antes de realçar a função desses elementos como recursos ideológicos na construção da identidade social nacional.

${ }^{27}$ Mesmo no ambiente espetacular do Bumbá de Parintins, essa dimensão devocional está presente. O Boi Garantido preserva sua homenagem a São João em 23 de junho, e os Dois Bois, Garantido e Caprichoso, são devotos de N. Sra do Carmo, a padroeira da cidade cuja festa se inicia logo depois do festival.

${ }^{28}$ As narrativas de origem relacionam-se, por esse viés, às comédias e matanças maranhenses criadas em brincadeiras situadas nas margens do apoio oficial à cultura popular (Carvalho 2005). Como nos explica Seu Betinho: "falou em desejo, está dentro da origem" (versão 7). 


\section{Referências bibliográficas}

ABREU, Ovídio. 1983. "Dona Beija: análise de um mito". In: M. L. Cavalcanti, B. Franchetto e M. L. Heilborn (orgs.). Perspectivas antropológicas da mulher 3. Rio de Janeiro: Zahar Editores. pp.73-108.

ABREU, Martha. 1998. "Mello Moraes Filho: festas, tradições populares eidentidade nacional". In: S. Chaloub e L.M. Pereira (orgs.), A história contada. Rio de Janeiro: Nova Fronteira. pp. 171-193. 2004. "Outras histórias de Pai João: conflitos raciais, protesto escravo e irreverência sexual na poesia popular. 1880-1950". Afro-Ásia, 3:235-276.

ALBERNAZ, Lady Selma Ferreira. 2004. O "urrou" do boi em Atenas: instituições, experiências culturais e identidade no Maranhão. Tese de doutoramento. Unicamp.

ALMEIDA, Renato. 1942. História da música brasileira. Rio de Janeiro: Ed. Briguiet.

ANDRADE, Mário de. 1982. "As danças dramáticas do Brasil". In: O. Alvarenga (org.), Danças dramáticas do Brasil. $1^{\circ}$ tomo. Belo Horizonte: Ed. Itatiaia /Instituto Nacional do Livro/ Fundação Nacional Pró-Memória. pp. 23-84.

AVÉ-LALLEMANT, Robert. 1961. Viagem pelo Norte do Brasil no ano de 1859. Rio de Janeiro: Instituto Nacional do Livro, Ministério da Educação e Cultura.

AZEVEDO, Artur. 1906. "O Bumba-meuboi". Revista Kosmos, 2:9-14.

AZEVEDO NETO, Américo. 1983. Bumba-meu-boi no Maranhão. São Luís do Maranhão.

BARLTETT, Frederic Charles. 1965. "Some experiments in the reproduction of folkstories". In: A. Dundes (org.), The study of folklore. New
Jersey: Engleewood Cliffs, PrenticeHall. pp. 243-258.

BELMONT, Nicole. 1986. "Le folklore refoulé, ou les séductions de l'archaisme". L'Homme, XXVI (12):259-268.

BORBA FILHO, Hermilo. 1966. Apresentação do bumba meu boi. O Boi misterioso de afogados. Recife: Imprensa Universitária.

BORDALLO DA SILVA, Armando. 1981. Contribuição ao estudo do folclore amazônico na Zona Bragantina. Bragança: FUNARTE / Fundação Cultural de Bragança.

BOYER, Véronique. 1999. "O pajé e o caboclo: de homem a entidade". Mana. Estudos de Antropologia Social, 5(1):29-56.

BRAGA, Sérgio. 2001. Os bois-bumbás de Parintins. Tese de Doutoramento, USP.

BURKE, Kenneth. 1966. Language as symbolic action. Berkeley: University of California Press.

CARNEIRO, Édison. 1962. "A evolução dos estudos de folclore no Brasil". Revista Brasileira de Folclore, 3:47-62. 1974. Folguedos tradicionais. Rio de Janeiro: Ed. Conquista.

CARVALHO, Luciana. 2004. "O desejo de Betinho e o decreto do presidente". In: Celebrações e saberes da cultura popular. Série Encontros e Estudos n. 5. Rio de Janeiro: CNFCP, Funarte / IPHAN. pp. 85-94. 2005. A graça de contar: as narrativas de um Pai Francisco no bumba-meu-boi do Maranhão. Tese de Doutoramento, IFCS/UFRJ.

CARVALHO, Maria Michol. 1995. Matracas que desafiam o tempo: é o bumba-meu-boi do Maranhão. São Luis/ Maranhão. 
CASCUDO, Câmara. 1952. Literatura oral. Rio de Janeiro: Livraria José Olympio Editora. 1965. Antologia do folclore. Vol. I. São Paulo: Livraria Martins Editora. 1984. Dicionário de folclore brasileiro. Belo Horizonte: Ed. Itatiaia. $5^{\text {a }}$. ed.

CAVALCANTI, Maria Laura. 1994. Carnaval carioca: dos bastidores ao desfile. Rio de Janeiro: Ed. UFRJ.

2000. "O boi-bumbá de Parintins: breve história e etnografia da festa". Revista História,Ciência e Saúde: Visões da Amazônia, VI(suplemento especial):1019-1046

2002a. "Os sentidos no espetáculo". Revista de Antropologia, 45(1): 37-89.

2002b. "O indianismo revisitado pelo boi-bumbá: notas de pesquisa". Somanlu. Revista de Estudos Amazônicos, 2:127-135.

2004. "Cultura popular e sensibilidade romântica". Revista Brasileira de Ciências Sociais, 19(54):57-78.

CAVALCANTI, Maria Laura et alii. 1992. "Os estudos de folclore no Brasil". In: Folclore e cultura popular: as várias faces de um debate. Rio de Janeiro: Funarte/CNFCP. pp.101-112.

CNFCP. 2003a. CD-Rom. Tesouro de folclore e cultura popular. Rio de Janeiro: CNFCP/IPHAN/Minc. 2003b. CD-Rom. Bumba-meuboi do Maranhão. Rio de Janeiro: CNFCP/IPHAN/Minc

DA MATTA, Roberto. 1973. "Panema: uma tentativa de análise estrutural". In: Ensaios de antropologia estrutural. Petrópolis: Vozes. pp.63-92. 1979. "Pedro Malazartes e os paradoxos da malandragem" e "A hora e a vez de Augusto Matraga". In: Carnavais, malandros e heróis. Rio de Janeiro: Zahar Editores. pp.260-301 e 305-334.
1987. “Digressão: a fábula das três raças, ou o problema do racismo à brasileira". In: Relativizando: uma introdução à antropologia social. Rio de Janeiro: Ed. Rocco. pp. 58-85. 2000. "Individualidade e liminaridade: considerações sobre os ritos de passagem e a modernidade". Mana. Estudos de Antropologia Social, 6(1):7-29.

DÉTIENNE, Marcel. 1992. A invenção da mitologia. Brasília/Rio de Janeiro: Ed. UnB / José Olympio Editora. 1987. "Mito/Rito". In: Enciclopédia Einaudi, vol. 12. Lisboa: Imprensa Nacional. pp. 59-74.

DUARTE, Luiz Fernando Dias. 2004. "A pulsão romântica e as ciências humanas no Ocidente". Revista Brasileira de Ciências Sociais, 19(55):5-18.

DURKHEIM, Émile. 1978. As regras do método sociológico. São Paulo: Ed. Nacional. 1996. As formas elementares da vida religiosa. São Paulo: Martins Fontes.

DUMONT, Louis. 1970. Homo hierarchicus. Madrid: Aguilar. 1987. La tarasque. Paris: Gallimard.

FERREIRA, Ascenso. 1944. "O bumbameu-boi". Arquivos, 1-2:121-157. Prefeitura Municipal do Recife.

FREYRE, Gilberto. 1977. Sobrados e mucambos. Rio de Janeiro: Livraria José Olympio Editora.

GALVÃO, Eduardo. 1951. "Boi-bumbá: versão do Baixo Amazonas. Anhembi, 3(8):275-291.

GONÇALVES, José Reginaldo. 1997. A retórica da perda. Rio de Janeiro: Editora da UFRJ.

GOODY, Jack. 1977. "Mémoire et apprentissage dans les sociétés avec et sans écriture: la transmission du bagre". L'Homme, 1:29-52. e WATT, Ian. 1968. "The consequences of literacy". In: J. Goody (org.), Literacy in traditional societies. 
Cambridge: Cambridge University Press. pp. 27-68.

HOBSBAWN, Eric. 2002. "A invenção das tradições". In: E. Hobsbawn \& T. Ranger (orgs.) A invenção das tradições. Rio de Janeiro: Paz e Terra. pp.9-23.

JAKOBSON, Roman. 2003. "Dois aspectos da linguagem e dois tipos de afasia". In: Lingüística e comunicação. São Paulo: Cultrix. pp.34-62

JAKOBSON, Roman e BOGATYREV, Peter. 1973 [1929]. "Le folklore, forme spécifique de la création" In: R. Jakobson (org.), Questions de poétique. Paris: Éditions du Seuil. pp. 59-72.

LANNA, Marcos. 1995. A dívida divina. Troca e patronagem no Nordeste brasileiro. Campinas: Ed. Unicamp.

LEACH, Edmund. (org.). 1967. The structural study of myth and totemism. London: Tavistock Publications.

LEACH, Edmund. 1969. Genesis as myth, and other essays. London: Cape Editions.

LIMA, Carlos. 1982. Bumba-meu-boi. São Luís: Augusta. 3 ed.

LOPES GAMA, Miguel. 1996. "A estultice do bumba-meu-boi". In: O carapuceiro. São Paulo: Cia das Letras. pp.330-338.

LOPEZ, Telê. 1972. Mário de Andrade: ramais e caminhos. São Paulo: Duas Cidades.

LÉVI-STRAUSS, Claude. 1967. Antropologia estrutural. Rio de Janeiro: Tempo Brasileiro.

. 1971. L'homme nu. Paris: Plon. 1976.O pensamento selvagem. São Paulo: Cia. Ed. Nacional. . 1993. Antropologia estrutural dois. Rio de Janeiro: Tempo Brasileiro.

MARQUES, Ester. 1999. Mídia e experiência estética na cultura popular. $O$ caso do bumba-meu-boi. São Luís: Imprensa Universitária.

MATOS, Edilene. 2002. “Estórias de boi na literatura popular". XVI Moitará, Sociedade Brasileira de Psicologia Analítica. Campos de Jordão. Ms.

MAUSS, Marcel. 1967. Manuel d'éthnographie. Paris: Petite Bibliotéque Payot.

. 1978. "Essai sur le don: forme et raison de l'échange dans les sociétés archaiques". In: Sociologie et anthropologie. Paris: PUF. pp. 143-279.

MELLO E SOUZA, Gilda. 1979. O tupi e o alaúde. São Paulo: Duas Cidades.

MENEZES, Bruno. 1972. Boi-bumbá, auto popular. Belém: Imprensa Oficial.

MEYER, Marlyse. 1991. "O elemento fantástico numa forma de teatro popular brasileiro". In: Pirineus, caiçaras. Campinas: Editora da Universidade. pp. 55-70.

MONTEIRO, Mário Ypiranga. 1972. Folclore: danças dramáticas. Manaus: EMANTUR.

MORAES, Eduardo Jardim. 1978. A brasilidade modernista: sua dimensão filosófica. Rio de Janeiro: Graal. 1983. A constituição da idéia de modernidade no modernismo brasileiro. Tese de doutorado, Rio de Janeiro, Departamento de Filosofia, IFCS/UFRJ.

1992. "Modernismo e folclore". In: Folclore e cultura popular: as várias faces de um debate. Série Encontros e Estudos, n. 1. Rio de Janeiro: Funarte/ CNFCP. pp. 75-78.

1999. Limites do moderno: o pensamento estético de Mário de Andrade. Rio de Janeiro: Relume Dumará.

QUEIROZ, Maria Isaura Pereira de. 1967. "O bumba-meu-boi, manifestação do teatro popular no Brasil". Revista do Instituto de Estudos Brasileiros, 2:87-97.

PEREIRA DA COSTA, Francisco Augusto. 1908. Folklore Pernambucano. Revista do Instituto Histórico e Geográfico Brasileiro, LXX, II. Rio 
de Janeiro: Instituto Histórico e Geográfico Brasileiro.

PRADO, Regina. 1977. Todo o ano tem: as festas na estrutura social camponesa. Dissertação de Mestrado, PPGAS/ Museu Nacional/ UFRJ.

ROMERO, Sílvio. 1954. Cantos populares do Brasil. Tomo I. Rio de Janeiro: Livraria José Olympio Editora.

SACRAMENTO, Domingos. 1979. Crônica interna, Semanário Maranhense. São Luís: Ed Siege. pp. 7-8.

SAHLINS, Marshall. 1999. "Two or three thing that I know about culture". The Journal of the Royal Anthropological Institute, 5(3):399-421.

SALLES, Vicente. 1970. "O boi-bumbá no ciclo junino". Brasil Açucareiro, 38:27-33.

SANCHES FRIAS, D. C. 1883. Uma viagem ao Amazonas. Lisboa: Typographia de Mattos Moriera \& Cardoso.

STOCKING JR., George W. 1989. "The ethnographic sensibility of the 1920s and the dualism of the anthropological tradition". In: __. (org), Romantic motives. Essays on anthropological sensibility. Madison: The University of Winsconsin Press. pp. 208-279.

TURNER, Victor. 1957. Schism and continuity in an African society. Manchester: Manchester University Press. . 1971. "An anthropological approach to the Iceland Saga". In: The translation of culture. Essays to E. E. Pritchard. New York: Tavistock Publications. 2005 [1967]. "Betwix and between: o período liminar nos ritos de passagem". In: Floresta de símbolos: aspectos do ritual ndembu. Niterói: EdUFF. pp. 137-158.

TRAVASSOS, Elizabeth. 1997. Os mandarins milagrosos: arte e etnografia em Mário de Andrade. Rio de Janeiro: Jorge Zahar Ed.

VALENTIN, Andréas. 2005. Contrários: a celebração da rivalidade dos bois-bumbás de Parintins. Manaus: Ed. Valer.

VALERI, Carlo. 1994. "Rito". In: Enciclopédia Einaudi, vol. 30. Lisboa: Imprensa Nacional/ Casa da Moeda. pp. 325-359.

VAN GENNEP, Arnold. 1978. Os ritos de passagem. Petrópolis: Vozes.

VERNANT, Jean-Pierre. 1999. "Razões do mito". In: Mito e sociedade na Grécia Antiga. Rio de Janeiro: José Olympio Editora. pp.71-221.

. 2001. "Formas de crença e de racionalidade na Grécia". In: Entre mito e política. São Paulo: Edusp. pp. 197-225.

VILHENA, Luiz Rodolfo. 1997a. Projeto e missão: o movimento folclórico brasileiro, 1947-1964. Rio de Janeiro: FGV/ Funarte. 1997b. "Leitura e práticas leitoras em sociedade". In: Ensaios de antropologia. Rio de Janeiro: EdUERJ. pp. 97-114.

ZENGOTITA, Thomas de. 1989. "Speakers of being: romantic refusion and cultural anthropology". In: G. W. Stocking Jr. (org.), Romantic motives: essays on anthropological sensibility (History of anthropology, vol. 6). Madison: The University of Wisconsin Press. pp. 74-123. 


\section{Apêndice: outras variantes}

A transcrição do conjunto das variantes consideradas sobrecarregaria este apêndice, assim sendo transcrevo apenas algumas narrativas, resumindo ou fornecendo a referência das demais.

Versão 2. Odinéia Andrade. Parintinense, professora, estudiosa de folclore e torcedora do Boi Caprichoso; entrevista concedida à pesquisadora em 21/06/1999.

O boi, para nós, [...] era um grupo de vaqueiros, o amo. Tinha o sacerdote, tinha o pajé, o feiticeiro, tinha o boi, tinha uns três ou quatro vaqueiros, tinha o índio [...] e o negro que era representado pelo Pai Francisco e pela Mãe Catirina. Então, esse casal era como se fossem os empregados da fazenda. Tinha o vaqueiro maior, que era o amo, e eles, sob orientação do amo, faziam os trabalhos da fazenda. E o Pai Francisco, para obedecer o desejo da mulher que queria comer a língua, o órgão vital do boi, o coração, o fígado, para nós, ficou sendo a língua. [...] O touro de raça, o touro de fama. E o pai Francisco, para que o filho dele não saísse aleijado, ele resolveu matar o touro do patrão. Aí então ele mata e resolve se esconder, porque ele sabia que ia ser castigado. Aí tá, vão à caça do Pai Francisco. O índio, porque conhece muito bem a selva, sai antes na selva atrás do pai Francisco e aí chama todo mundo, chama os vaqueiros e o padre, chama o doutor curador - eram os vários personagens. Tinha o rebolo. Em volta do boi os vários personagens, que através de uma cantoria cômica faziam o boi reviver. Espirrando debaixo do boi, levantava o boi. Tinha os versos que eles declamavam e iam fazendo as piruetas em volta do boi, até que o boi revivia e aí a alegria de todos. Começava de novo a cantoria e todo mundo festejava a ressurreição do boi [...].

Versão 3. Toada maranhense "Boi de Catirina" (compositor Ronaldo). CD Bandeira de Aço. Discos Marcus Pereira, do cantor Papete (Josias da Silva Sobrinho).O locutor é Pai Francisco:

Sinto frio e vergonha/que não cabe no meu peito/porque tenho que enganar/o meu boi com os pensamentos// Mas lá perto da fogueira/minha nêga me espera/Arredia e preguiçosa/Com criança na barriga/Cheia de desejamento...// Refrão: Ah, essa dor de ver/ Meu boi indo me olhar/E sem nada saber/Sem se defender/Chora meu boi...//Ah! bumba-boi, Bumba-bumbá/Me perdoa por querer/Sua língua só para dar/Pra essa nêga Catirina. 
Versão 4. Relato escrito de Casemiro Anastácio Avelar, brincante de bumba-meu-boi de São Luís do Maranhão, endereçado a Renato de Almeida e Édison Carneiro (Carneiro 1974:205-206).

Eu conto a estória do bumba-meu-boi assim como o meu avô José Ponciano Avelar sempre me explicava na base de uma estória que o bumba-meu-boi foi iniciado no sertão do Ceará quando havia a escravidão. Em uma fazenda de um coronelão tinha muitos escravos, onde tinha um de toda confiança que adotava o nome de Pai Francisco e uma cozinheira mulata, o seu nome era Catirina, mas todos chamavam de Catita. Nesta mesma fazenda havia um boi com o nome de Boi Barroso. O Pai Francisco e a Catita se namoravam. Passado algum tempo, a Catita disse ao Pai Francisco que estava grávida e tinha desejado comer um pedaço de fígado, mas só servia do boi Barroso. E continuava insistindo. O Pai Francisco mostrava-se aborrecido e falava a ela que não podia fazer isto porque esse boi era de toda estimação, o mais querido da fazenda e o mais cobiçado por todos. Mas uma das vezes a Catita o iludiu, dizendo que estava para perder o culumim. Esta conversa levou Pai Francisco ao abismo. Ele tinha o seu rancho retirado da fazenda. Um dia pegou o Boi Barroso, matou, enterrou o couro e o fato e deixou de ir na fazenda. O coronel procurava saber notícias de Pai Francisco, os seus parceiros não davam informação. A Catita, por sua vez, vivia um pouco desconfiada. Um dia um dos seus amigos, que estava em uma caçada, sentiu um cheiro de carne assada. Lembrou-se de Pai Francisco. Com mais alguns passos chegou ao rancho de Pai Francisco.

Este ficou muito vergonhoso e o seu amigo disse que, ao chegar na fazenda já encontrou todos sob as ordens do coronel para dar notícias de Pai Francisco para não serem castigados. Este último informou que tinha visto Pai Francisco comendo carne assada [...]. Pai Francisco quando viu conversa de mais de uma pessoa deixou a sua caverna e procurou fugir. Com muita dificuldade pegaram Pai Francisco, trouxeram para a fazenda. Pai Francisco quando chegou à presença do coronel dava ataque, ao ser interrogado mentia dizendo que não tinha sido ele. O coronel mandou botar de castigo, prometeu-lhe mandar cortar o pescoço. Pai Francisco confessou-se, explicando para o coronel que, se um dia fosse posto em liberdade, dava uma surra em Catirina. Depois de alguns meses, se aproximou o mês de junho. O coronel avisou aos seus escravos para fazer uma festa onde se achava Pai Francisco detido, amarrado, dizia o coronel: "Aporrinho ele, por que tu foste matar o boi do Sr. coronel?" A 23 de junho, os escravos fizerem uma enorme fogueira em frente à casa do coronel e foram buscar Pai Francisco, formaram um círculo, deixando Pai Francisco no meio daquela roda, batendo palmas, e diziam: "bate palma e bate pé/ foi Pai Francisco quem / matou o boi do coronel/por causa da mulher. 
Depois continuaram a fazer festa todos os anos, pois o coronel tinha gostado muito de ver como pai Francisco ficava zangado [...].

\section{O narrador prossegue:}

Assim me contava meu avô José Ponciano Avelar. Este quando faleceu, eu contava com 15 anos de idade. Em 1935 eu já saía na brincadeira de bumbameu-boi, mas já não era mais esse sistema que acabo de contar (grifo meu). De acordo com os tempos que foram passando foi modificando [...].

Versão 5 . O relato de Laurentino, amo de boi em São Luís do Maranhão, já falecido em 1983, em relato a Azevedo Neto (1983:73-75).

Era uma vez,

um homem chamado Francisco, também chamado Pai Francisco, homem honesto e pacato, embora um tanto grotesco e caricato, cuidando de um boi de propriedade de um certo senhor. Chico era casado com Catirina. Um dia...

- Chico, estou com desejo! - Quem tem desejo é mulher grávida.

- Mas eu estou grávida. - Então é desejo. - Mas não é o que estou dizendo?! - E é desejo de quê? - Desejo da língua do boi Barroso

Diante de tal situação, Chico, embora assustado, não hesitava: atirava no boi, cortava-lhe a língua, satisfazia o desejo de Catirina e, com a mulher, fugia da fazenda. Dando pela falta do boi e pela ausência de Chico, o amo chamava os índios e lhes ordenava que procurassem por pai Francisco, pelo boi e os trouxessem de volta à fazenda. Os índios saíam e logo encontravam o fugitivo: Chico, no entanto, reagia e os índios reclamavam:

-Amo, Chico me atirou. Eu pulei pra trás. Tiro não pegou.

Chico esbravejava: - "Eu sou nego duro, duro, moradô dos arraiá/ Queimo no seco, queimo no inverno/

Nunca deixo de queimá/Tenho espingarda véia/Que pesa 3.500 quintá/Só vou lá Com cinco ou seis caboco reá".

Mas Chico acabava capturado, sendo levado pelos índios até a presença do amo, juntamente com Catirina e com o cadáver do boi. Imediatamente era chamado o curador que, logo após constatar a morte, cantava: - "Quem matou este boi/ boi de fama, boi de peso/Eh! Pai francisco, foi tu!/Amo, cheire a boca do boi/ E Chico, tu cheira o cu."

Chico, porém, reagia: - "Se alguém me conheceu/ já se viu que tu não foi/Não sou home pra essas coisa. De cheirá um cu de boi."

Indignado ante a recusa, o amo mandava que batessem em Chico, Catirina tentava intervir, mas era ameaçada de ser surrada também. Depois de apanhar, 
TEMA E VARIANTES DO MITO: SOBRE A MORTE E A RESSURREIÇÃO DO BOI

Pai Francisco acabava por confessar o furto e por admitir a idéia de colaborar no tratamento do boi.

A cena, então, era do pajé: cantava e dançava até que seus trabalhos surtiam efeito e o boi ressuscitava, dando um grande urro como sinal

- "Urrou! Urrou!/Urrou que ouvi!/Boi mais bonito que este/Garanto que nunca vi!/Urrou! Urrou!/Urrou fama reá!/Boi de fama como este/No sertão não haverá."

Era o perdão de Chico, era a cantoria, era a festa.

Obs: outro informante de Américo de Azevedo Neto, seu Isac (mestre de música e chefe de orquestra em Coroatá, na Baixada maranhense) e "Chico Pretinho" (morador do Pau de Estopa) comentaram que há muito tempo, nos bois da região do Mearim e do Itapecuruu, era comum Catirina abortar no exato momento do urro do boi, pois Chico, embora furtasse o boi, não chegava a cortar-lhe a língua. Mas o autor comenta que "não pode reconstituir como isso era teatralizado" (1983:78).

Versão 6. Relato de amo Leonardo a Américo de Azevedo, São Luís do Maranhão. Em 1983, Leonardo era amo há 40 anos e brincante há 70 anos (Azevedo Neto 1983:78).

Versão 7. A "Matança do vaqueiro fiel", de autoria de Seu Betinho, Herberth Mafra Reis, Pai Francisco do Bumba-meu da Fé em Deus, São Luís do Maranhão. História idealizada, porém não encenada, foi narrada para Luciana Carvalho (Carvalho 2005:469-473).

Versão 8. "Estória e Comédia do Boi Caprichoso", texto do Sr. Francisco Araújo da Silva, enviado a Édison Carneiro e a Bruno de Menezes (Carneiro 1974:207-212). Menezes era folclorista e é o autor de outro registro (Menezes 1972), apresentado no Primeiro Congresso Brasileiro de Folclore, no Rio de Janeiro, em 1951, como uma contribuição do Pará.

9. Versão de Soraya (estudante parintinense e membro da batucada do Boi Garantido; entrevista concedida à autora na cidade de Garantido, em 23/06/1999.

O Pai Francisco, ele era o capataz da fazenda. A mulher dele, a Catirina tava grávida, então ela desejou comer a língua do boi, do boi Garantido, né? Que era o boi mais bonito da fazenda. Aí, pro Pai Francisco não perder o filho dele - porque antigamente esse negócio de desejo, dizia-se que quando o desejo não era realizado, a criança nascia com a cara do bicho que a mãe desejava 
comer, com a cara de fruta, e assim se fala. Aí ela desejou, ela desejou comer a língua do boi. Aí o Pai Francisco foi lá, não matou o boi, só puxou a língua dele e cortou e fez. Só que o boi ficou se debatendo lá, e ele pensou que o boi tinha morrido. Quando foi depois o boi sumiu. Só que quando chegava a noite, o boi aparecia para o Pai Francisco e para a Mãe Catirina atormentando. Aí vira essa lenda. Como o Pai Francisco não podia mais devolver a língua do boi porque a Catirina já tinha comido, ele fez uma promessa: que ele ia velar o boi e que ele nunca mais ia comer carne de boi [...].

Soraya então canta uma toada antiga do boi Caprichoso:

Chega a Catirina do Boi, oi, oi, oi oi/ Chega a Catirina do Boi, oi, oi, oi oi/ Com desejo de comer a língua,/ tira a língua do meu Boi./ Vem brincar de Boi-Bumbá./ Pai Francisco e Catirina./ A festa vai começar./ Bumba, bumba, bumba boi,/ vem brincar de Boi-bumbá./ Bumba, bumba, bumba boi,/vem brincar de boi-bumbá. 


\section{Resumo}

O texto indaga sobre a presença e o sentido de processos míticos relacionados ao folguedo do boi, em uma abordagem de inspiração estruturalista. A primeira parte trata de desconstruir a difundida idéia de que o folguedo do boi corresponderia, ou teria correspondido em suas supostas origens, à encenação de um auto. Argumento que essa crença é um notável efeito da ilusão do arcaísmo característica dos estudos de folclore. Reformulando o "problema do auto", proponho sua compreensão como um conjunto de narrativas de origem que emerge da bibliografia em meados do século XX. Trata-se de demonstrar a natureza mítica dessas narrativas. As conclusões, seguindo sugestões da análise realizada, buscam situar em nova perspectiva a relação entre mito e rito na brincadeira do boi.

Palavras-chave: Mito, Rito, Bumbameu-boi, Análise estrutural, Narrativas de origem

\section{Abstract}

This text discusses the presence and meaning of mythic processes related to the folguedo do boi ('the revelry of the ox'), adopting a structuralist-inspired approach. The first part deconstructs the widespread idea that the folguedo do boi corresponds, or orginally corresponded, to the performance of a folk play or auto. I argue that this belief is a clear example of the illusion of archaism typically fostered by folklore studies. Reformulating the 'problem of the auto,' I propose comprehending it as a set of origin narratives which emerge in the literature in the middle of the $20^{\text {th }}$ century. The text works to demonstrate the mythic nature of these narratives. The conclusions reached by this analysis enable a fresh perspective on the relation between myth and rite in the folguedo do boi.

Key words: Myth, Rite, Bumba-Meu-Boi, Structural Analysis, Origin Narratives 